\title{
DETERMINANTS OF HEARING LOSS IN WORKERS AT PRODUCTION UNIT OF A FACTORY
}

\author{
Decy Situngkir, Mia Mutingah
}

Universitas Esa Unggul, Jakarta, Indonesia

\begin{abstract}
Background: Occupational hearing loss is the most common work-related illnesses globally. Based on the results of the audiometric test at a factory, as many as 139 out of 826 workers in production unit had hearing loss. This study aimed to determine factors associated with hearing loss in workers.

Subjects and Method: This was a cross-sectional study conducted at a factory in Jakarta, from March to July 2018. A sample of 51 workers who worked in production unit was selected for this study using stratified random sampling. The dependent variable was hearing loss. The independent variables were age, length of work, and personal protection equipment (PPE) use. Hearing loss was measured by audiometry examination, which information was obtained from the medical record. The data for independent variables were collected using observational sheet and a set of questionnaires. Bivariate data analysis was performed by chi-square, with prevalence ratio (PR) as the measure of association.

Results: The risk of hearing loss in workers from production unit at a factory increased with older age $(\mathrm{PR}=1.83 ; 95 \% \mathrm{CI}=1.07$ to $3.12 ; \mathrm{p}=0.025)$, longer work $(\mathrm{PR}=$ $2.20 ; 95 \% \mathrm{CI}=1.16$ to $4.18 ; \mathrm{p}=0.009)$, and poor $\mathrm{PPE}$ use $(\mathrm{PR}=2.60 ; 95 \% \mathrm{CI}=1.20$ to 6.20; $\mathrm{p}=0.012$ )
\end{abstract}

Conclusion: The risk of hearing loss in workers from production unit at a factory increases with older age, longer work, and poor PPE use.

Keywords: hearing loss, age, PPE, length of work, workers

\section{Correspondence:}

Decy Situngkir. Universitas Esa Unggul. Jl. Arjuna Utara 9, Kebun Jeruk, Jakarta Barat. Email: decy.situngkir@esaunggul.ac.id. Mobile: 08983697021 